\section{The making of a great scientist}

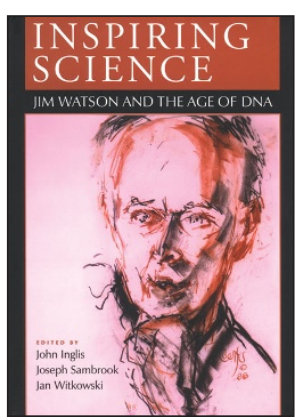

\section{Inspiring Science: Jim Watson and the Age of DNA}

Edited By John Inglis, Joseph Sambrook \& Jan A Witkowski

CSHL Press, 2003

503 pp. hardcover, $\$ 35.00$

ISBN 0-87969-698-2

Reviewed by Thomas Lazar

Scientific discoveries, as we learn from the dustjacket of Inspiring Science, tend to be made when the time is ripe, rather than when "the scientist who was born to make it" appears on the scene. So what, then, makes a great scientist? A bright mind is a prerequisite, but one also needs a spoonful of good luck. James Watson was fortunate enough to be in the right place at the right time to beat his competitors to the "bride's bouquet" when, in 1953, the problem of elucidating the structure of DNA was hovering in midair.

Watson's scientific contributions alone would have secured him a place in the annals of genetics, but the story does not end there. After a more-than-successful stint at the bench, he proved to be equally successful in the boss' chair. To be a top-notch scientist requires a fundamentally different set of qualities than to be a successful manager. Logically, great names attract bright and eager young lions, but unlike the gravitational attraction of a black hole that pulls indiscriminately, building up a critical intellectual mass requires extraordinary insight. During his university career and long-standing commitment as director of the Cold Spring Harbor Laboratory, Watson proved that he is endowed with the ability to select, nurture and mentor the generation of scientists that succeeds him.

The reader of this book learns that Watson would not be a true star of the scientific world if he had confined himself to the ivory tower. Science, as any true scientist knows, has little to do with wearing a lab coat and mumbling arcane Latin and Greek words. Being a real scientist is a way of life, and Jim Watson is science personified. Many scientists, even the ones playing in the top league, shy away from the public. Few take the risk, as Watson frequently and willingly did, of facing the 'real world' and fully exposing themselves, at the risk of being misquoted, misunderstood and miscontrued. His role as an advocate of science, his sensible thinking and his seminal scientific discoveries have secured for him a lasting place in scientific history.

The fifty years since the double-helical solution to the riddle of heredity first came upon us coincide with seventy-five years of

Thomas Lazar is a freelance writer in Goettingen, Germany.

Tlazar@web.de
Watson's life, most of it spent unraveling the mysteries of living nature. Inspiring Science commemorates these joint anniversaries. It is a biography of an unusual kind, about an unusual man.

The book is a collection of some fifty "chapterlets," provided by an almost equal number of authors. All of them have been companions of the protagonist, and most have had the privilege of working with or for him. The essays vary greatly in style, content and length, ranging from trivial to insightful. Some are hardly more than 'happy birthday' notes, while others are verbose expeditions into the past. Although the resulting mosaic lacks the coherence and thought-out plot of a single-author biography, the pieces that the editors have chosen for this volume are an interesting mix. I was often surprised at the openness with which several contributing scientists wrote about the mechanics of the tough scientific business and the human touch of the people behind it.

Some of the invited authors seized the opportunity to provide distinctly autobiographical sketches, marked with an air of vanity, in which Jim Watson appears only peripherally. More than one essay involves the wide gap between the self-assured feeling of importance that many top scientists (maybe justifiably) have, and the almost complete neglect of the 'real world' in recognizing their worth. In addition to many details about the authors themselves, we learn about the man upon whose lifetime achievements this book centers, as well as the idiosyncrasies that add to his distinct personality.

I admit to more than a slight degree of ill-concealed admiration (plus a spoonful of envy) for a man who has the guts to stand up during a boring and overly long talk of a colleague and shout, "Shut up! We're fed up with this." This being said, one can hardly complain about Watson's habit of occasionally departing abruptly in the middle of a conversation, leaving behind a perplexed and embarrassed person. What seems to be acceptable behavior for a Nobel laureate could easily bring the career of an average scientist to a premature end. Yet any reader will probably recall more than one occasion when he/she would have liked to have done the same.

History-making scientist of international fame, successful manager of one of the best biological think-tanks, standard-setting textbook author, popularizer and public advocate of science, government advisor: "Jim of all trades" be his nom de guerre. Inspiring Science brings us closer to a seemingly larger-than-life man whose long shadow will be cast far into the twenty-first century. Without him, someone else would sooner or later have solved the mystery that half a century ago surrounded DNA. But there is no doubt that Watson had a profound effect on the development of molecular biology in the second half of the twentieth century. He is one of the truly powerful puppeteers of the scientific world, pulling the strings on which the rest of us dangle and dance. Inspiring Science reveals that behind the awe-inspiring public image is a human being with the usual set of strengths and weaknesses, qualifications and shortcomings.

Inspiring Science will be not so much remembered for its literary accomplishments as it will be cherished by historians and psychologists as a precious time capsule laying bare the mechanics of science at the end of the twentieth century. Inspiring Science is inspiring reading. 